\title{
A CHRISTIAN-BUDDHIST DIALOGUE ON THE FOUR NOBLE TRUTHS
}

\author{
Joseph Mwangi Munyua, PhD* \\ *1 https://orcid.org/0000-0003-2551-9194 jmmunyua1948@gmail.com, +2540724 384757 Protestant-Catholic \\ Systematic Theologian Adjunct Lecturer and Research Consultant, St. Paul's University, Kenya
}

*Corresponding Author: -

Email: jmmunyua1948@gmail.com

\begin{abstract}
: -
For the first time, in the Vatican Council II (1962-65), the Catholic Church recognized non-Christian religions as entities that the Church should respect and with which Christians should enter into dialogue. Being on the same page, the World Council of Churches (WCC) affirms that from her initiation, the Church has been confessing that God is reconciling the world to Himself via His Son and has given us the ministry of reconciliation. Again, the WCC holds that, throughout history, the Church has been seeking to apply the basics of her faith to concrete situations in which she has been finding herself in her endless missiological journeys. Nowadays, the Church is called upon to empower her members to relate to people of other religions and to live as witnesses with others. These points justify the necessity of this article, which is entitled "A Christian-Buddhist Dialogue on the Four Noble Truths." In the context of interreligious dialogue, this article seeks to explain the four Noble Truths of Buddhism in the light of Christian Soteriology. To that end, this article begins with a simplified explanation of the four Noble Truths of Buddhism after which it seeks to re-explain and re-express the same noble truths in the light of Christian Soteriology. Ultimately, this article reveals that Christians and Buddhists can borrow from each other towards enriching their respective soteriologies. Regarding its methodology, this article employs the review of the relevant literature, the principles of Nostra Eatate No. 2, the comparative method, and rational reflection.
\end{abstract}

Keywords: - Interreligious Dialogue, Four Noble Truths, Soteriology, Sin, Fall, Buddhism, Buddha

\section{(c) $(\$)$}




\section{INTRODUCTION}

Strictly, interreligious dialogues seek to cement human relationships. To that end, the WCC interreligious office seeks to build bridges of trust and respect with other religions and to develop interreligious solidarities, which can lead to justice, peace, and the wellbeing of the entire creation. Along the same lines, on October 28, 1965, Pope Paul VI made the declaration on the relation of the Church to non-Christian religions (nostra aetate) in which he firmly says the following things:

Buddhism, in its various forms, realizes the radical insufficiency of this changeable world; it teaches a way by which men, in a devout and confident spirit, may be able either to acquire the state of perfect liberation, or attain, by their own efforts or through higher help, supreme illumination. Likewise, other religions found everywhere try to counter the restlessness of the human heart, each in its own manner, by proposing "ways," comprising teachings, rules of life, and sacred rites. The Catholic Church rejects nothing that is true and holy in these religions. She regards with sincere reverence those ways of conduct and of life, those precepts and teachings which, though differing in many aspects from the ones she holds and sets forth, nonetheless often reflect a ray of that Truth which enlightens all men. Indeed, she proclaims, and ever must proclaim Christ "the way, the truth, and the life," 12 in whom men may find the fullness of religious life, in whom God has reconciled all things to Himself. ${ }^{2}$

The Church, therefore, exhorts her sons, that through dialogue and collaboration with the followers of other religions, carried out with prudence and love and in witness to the Christian faith and life, they recognize, preserve and promote the good things, spiritual and moral, as well as the socio-cultural values found among these men. ${ }^{3}$

In the spirit of the above Pope Paul VI's appeal for interreligious dialogues, it is important to acknowledge our religious diversity as well as promote unity in religious diversity and religious diversity without fragmentation. Certainly, it is true that we are, but it is true that others are too. In that vein, we are because they are and without them we cease to be what we were meant to be, namely, humane relational beings. Precisely, therefore, interreligious dialogues are meant to boost religious tolerance and promote peaceful co-existence on the globe that houses all of us.

Cautiously, using the above-quoted words of Pope Paul VI, we can observe that the four Noble Truths of Buddhism are liberating teachings that depict the radical insufficiency of this changeable world. Again, the said truths teach a way by which people may be able to either acquire the state of perfect liberation or attain supreme illumination. In view of that, the Catholic Church regards with sincere reverence the teachings of Buddhism that, even if they differ in many aspects from the ones she holds and sets forth, often reflect a ray of that Truth which enlightens all people. In this case, Pope Paul VI calls upon the members of the Church to enter into a genuine dialogue and collaboration with the followers of other religions and, therein, seek to prudently recognize, preserve, and promote the good things, spiritual and moral, as well as the socio-cultural values found among the said other religions. ${ }^{4}$

It is in the above context that this article adheres to the dialogue of theological exchange in which it seeks to bring about a Christian-Buddhist dialogue on the four Noble Truths. In the said dialogue, there is an attempt to recognize, preserve, and promote some of the good things that are found in Buddhism. Specifically, as regards the aforesaid dialogue of theological exchange, this article seeks to explain the four Noble Truths of Buddhism in the light of Christian Soteriology. First, this article will concisely strive to explain the four Noble Truths of Buddhism. Then, it will seek to re-explain and re-express the same noble truths in the light of Christian Soteriology. It is to these imperatives that we now turn.

\section{The Four Noble Truths of Buddhism ${ }^{5}$}

Buddhism is a major world religion that arose in the sixth century BCE. This faith was founded in northeastern India. Basically, Buddhism is an offshoot of Hinduism that, after its emergence, suddenly developed in a distinctive direction. Strictly, Buddhism is based on the teachings of Siddhartha Gautama, the Buddha. Also, Buddhism takes its name from the epithet of Siddhartha Gautama, namely, the Buddha. The term Buddha means enlightened one, a knower Generally, the anticipated future of many religions is either annihilation or eternalism. On the contrary, Buddhism teaches the middle path in which its ultimate goal is neither annihilation, because there is nothing permanent to annihilate, nor eternalism, because there is no permanent soul to eternalize. In Buddhism, the ultimate goal can be attained in this very earthly life. In that vein, the Buddha urges his followers to depend on themselves for their salvation. This soteriological position of the Buddha is based on his moral religious claim, that is, both defilement and purity depend on oneself. It is in this context that Buddhists hold that nobody can directly purify or defile another person.

Buddhists strive for enlightenment in an attempt to attain nirvana. ${ }^{10}$ In Hinduism, Buddhism, and Jainism, nirvana means the attainment of enlightenment and freeing of the spiritual self from attachment to worldly things. After attaining nirvana, an individual puts to an end samsara, that is, the endless cycle of birth, death, and rebirth. Precisely, the four Noble Truths of Buddhism shows how an individual can attain the

"K. Main," An Introduction to Buddhism, The Four Noble Truths, and The Eightfold Path, accessed October 25, 2020, https://www.yogiapproved.com/om/buddhism-four-noble-truths-eightfold-path/ aforesaid enlightenment. For that reason, the essence of Buddha's teachings is the said four Noble Truths, namely, the truth of suffering, the truth of the cause of suffering, the truth of the end of suffering, and the truth of the path that leads to the end of suffering.

The first Noble Truth is that human life is permeated with an inevitable suffering ( $u k k h a)$. Therefore, human existence is painful from the time of birth to the time of death. Indeed, even death brings no relief because it is followed by samsara,

\footnotetext{
${ }^{1}$ John 14:6

${ }^{2}$ Corinthians 5:18-19

${ }^{3}$ Paul VI, Declaration on the Relation of the Church to Non-Christian Religions, Nostra Aetate, 1965, in AAS 58 (1966), No. 2
} 
which is the Indian idea of life as cyclical, wherein death leads to further rebirth. ${ }^{14}$ Human suffering manifests itself as pain, illness, trauma, old age, poverty, corruption, poor working conditions, death, rebirth, and so forth. Accordingly, human life is agonising, empty, dissatisfying, imperfect, and impermanent. ${ }^{15}$ This situation leaves humanity in search of redemption, that is, a salvific solution. What follows this first Noble Truth is the following second Noble Truth in which the Buddha explains the cause of suffering. The second Noble Truth states the cause (origin) of the aforesaid suffering (Samudāya). The Buddha observes that all kinds of suffering are caused by sensual and mental desire (craving, lust, thirst, longing, or greed) (Tanha) ${ }^{4}$ which leads to rebirth. For him, this desire is triadic, that is, desire for pleasure, existence, and prosperity. ${ }^{5}$ Buddhism holds that desires are never satisfied; thus, one's desires can only cause suffering. So, Buddhism teaches that for one to attain nirvana, good and evil desires must be exterminated; the road to reaching the nirvana is to empty oneself from all desires. Typically, because desires cause suffering, extinguishing desires is tantamount to extinguishing suffering. This point leads us to the third and fourth Noble Truths of Buddhism. The third Noble Truth holds that cessation of suffering can be attained by overcoming all desires (Nirodha). The end of desire marks the end of suffering. If you do not desire, you cannot suffer. For example, if you do not desire for riches, your lack of riches cannot make you suffer. It is in this context that the fourth Noble Truth deals with the path that leads to the said cessation of suffering (Magga), namely, the Noble Eightfold Path, which consists of right belief (view), right intention, right speech, right action (co

At this point, the above outline of the four Noble Truths of Buddhism serves to give us the following informed reexplanation and re-expression of the said four Noble Truths in the light of Christian Soteriology. It is to this dialogic task that we now turn.

\section{The Four Noble Truths in the Light of Christian Soteriology}

In summary, the four Noble Truths of Buddhism entails an orderly voyage to the Buddhic salvation, namely, nirvana. Simply put, the four Noble Truths point out that life is permeated with suffering, suffering is caused by desire, suffering can be ceased by overcoming all desires, and the path that leads to the said cessation of suffering is the Noble Eightfold Path, which brings about the attainment of the above-mentioned nirvana. At this point, let us turn to the pinnacle of this article, namely, an innovative attempt to re-explain and re-express the aforesaid four Noble Truths in the light of Christian Soteriology.

\section{The First and the Second Noble Truths vis-à-vis the Fall}

Christianity holds that God created Adam and Eve in His likeness and image. In the said image and likeness, man enjoyed a threefold relationship, that is, one-on-one, God-man, and man-creation relationships. one attains the said second and final phase of nirvana, which is the nirvana without the body and the mind, the nirvana of no return (S. G. Kibicho, "A Comparative Study of Religions," in The Philosophical Foundation of Buddhist Teaching, ed. Jesse N. K. Mugambi (Nairobi: Nairobi University Press, 1990), 101-6.

However, man's freedom was limited and his dependence on his Creator was expected to manifest itself in his willful submission (obedience) to Him. Volitionally, thus, man was supposed to freely choose to obey God's command and adhere to the prohibition against eating of the tree of the knowledge of good and evil. But, man was tempted by the Devil after which he lost his trust in God and abused his freedom by disobeying God's command.

The above-mentioned first sin of man showed his disobedience to God and a lack of trust in His goodness. In his said first sin, man preferred himself to God; He chose himself over and against God, His Origin. Regarding his original state of holiness, man was destined to be fully divinized by God in glory. But, he was led astray by the Devil; in this case, man wanted to be like God, but without God, before God, and not according to God. As a result, man lost the original grace of holiness and justice. St. Paul evidences this reality by observing that "... all have sinned and fall short of the glory of God..."

In consequence, sin became universal and, therein, man was deprived of original holiness and justice. Undoubtedly, because of peccatum originale (original sin), human nature, without being totally corrupted, became wounded in its natural powers; it is now inherently bent towards sin. In this new dark milieu, the mentioned earlier threefold relationship was marked by unquenchable lust and domination. The said lust is the passionate unsatisfiable desire for pleasure, existence, and prosperity, which causes human suffering. It is in this context that, in Buddhism, the second Noble Truth holds that the cause of human suffering is desire (lust). Indeed, because of the above-mentioned lust and domination, there emerged an immense erosion of the harmonious relationship between God and man, man and man, as well as man and his environment. Man's sin is his inability to love God, others, and the Mother Nature; his sin is lovelessness, which is a consequence of his aforesaid innate inclination towards sin. To be sure, because of the fall, the being became alienated from the Being, other beings, and the world in which he has his being. Today, this sad story is evidenced by man's unquenchable lust and domination that leads to the universal corruption and the resultant human sufferingIn that vein, as rightly held by the second Noble Truth of Buddhism, lust is the cause of human suffering.

In this context, it is evident that after the first sin, the entire world became tainted with sin, unquenchable lust, corruption, and suffering. In this case, the primary fall of $\operatorname{man}^{6}$ was followed by the secondary fall, namely, the downward fall. In view of that, as shown below, the sinful act of Genesis chapter three sets in motion a chain reaction of sin and lust, which

\footnotetext{
${ }^{4}$ Desire or craving is fuelled by ignorance (avijjā), that is, blindness to suffering, to its cause and possible release, to the connection between action and results, and especially to the construction of a self whose craving is to be satisfied.

${ }^{5}$ Kibicho, "A Comparative Study of Religions," 101-6.

${ }^{6}$ Genesis 3
} 
invites universal corruption and the resultant suffering. Accordingly, the sin of Adam continued with the sins of his descendants. This downward fall embraces the murder of Abel by Cain, the story of the Noah and the flood, which is characterized by the irretrievable evil of man, and the story of the Tower of Babel, which is characterized by the ill selfcenteredness of man. ${ }^{30}$ In practice, man and the globe in which he existed (and still exists) became (and are) rotten, permeated with lust, corruption, suffering, and in dire need of redemption.

The above scenario displays that, through original sin, human nature, without being totally corrupted, became wounded in its natural powers. Through original sin, as evidenced by the spirit of the first and the second Noble Truths of Buddhism, man became privatus boni (deprived of good) and vulneratus in naturalibus (wounded in his natural human existence). In view of that, as hinted by the first and the second Noble Truths of Buddhism, human nature became subject to ignorance, to suffering, and to the dominion of death. Worse still, because of its untamable lust, human nature became characterized by concupiscentia (concupiscence), namely, its natural inclination towards sin. Simply, these avowals evidence that man became implicated in Adam's sin. In support of this reality, St. Paul makes the following observation:

... sin entered the world through one man, and death through sin, and in this way death came to all men, because all sinned...just as the result of one trespass was condemnation for all men, so also the result of one act of righteousness was justification that brings life for all men...through the disobedience of the one man the many were made sinners, so also through the obedience of the one man the many will be made righteous

Overall, as demonstrated by the mentioned earlier downward fall, Adam's sin, via the unity of the human race, was transmitted to humanity and it became the sin of all his descendants because the whole human race is in Adam. Thus, Adam's sin was propagated to humanity through a natural transmission of human nature, which is deprived of original holiness and justice. It is because of the primary fall and the resultant downward fall that humanity and the world that houses it are permeated with lust, universal corruption, and the resultant suffering. Again, regarding the second Noble Truth of Buddhism, the said universal corruption that leads to human suffering is caused by lust, which resulted from the Adamic fall. Hence, as the first and the second Noble Truths of Buddhism hold, human life is permeated with suffering, which is caused by desire. Therefore, humanity desperately needs liberation. In this context, let us focus on the third and the fourth noble truths of Buddhism visà-vis the Paschal Mystery.

\section{The Third and the Fourth Noble Truths vis-à-vis the Paschal Mystery}

On the one hand, Christianity teaches that the fall and the resultant lust, universal corruption, and suffering leave humanity in a desperate need for salvation. On the other hand, the third Noble Truth of Buddhism holds that human suffering can be brought to an end, which means that there is a salvific cure for the said problem (suffering). To that end, Christian Soteriology embraces three defining elements, namely, God's purpose to save man (God's saving will) that is primarily expressed by the Christ-Event, Redeemer's Person and Work, and the application of redemption, through the work of the Holy Spirit, in the hearts and lives of people. Therefore, in Christianity, man can attain liberation from sin, lust, universal corruption, and suffering through the Paschal Mystery, that is, the Passion, the Death, and the Resurrection of Jesus Christ. Hence, Christianity and Buddhism agree that suffering can be ceased. But, do these two religions offer the same means of eradicating the said suffering? Here below, let us wrestle with this question.

The fourth Noble Truth of Buddhism holds that the route that leads to the cessation of human suffering is the Noble Eightfold Path, which consists of right belief (view), right intention, right speech, right action (conduct), right means of livelihood, right effort (endeavor), right mindedness, and right contemplation (meditation). According to Buddhism, this is the right path that leads to the cessation of suffering and the enjoyment of true peace and happiness. Buddhism teaches that humanity is able to redeem itself from suffering via the said Noble Eightfold Path that enables someone to attain nirvana and, therein, live a fulfilling life without desire and suffering. On the contrary, Christianity holds that the sinful man who is privatus boni and vulneratus in naturalibus cannot redeem himself. Christian Soteriology teaches that salvation of man from sin, desire, universal corruption, and suffering is attained via the Paschal Mystery. Ultimately, the said mystery leads to the visio beatifica (beatific vision), wherein the beings experience the direct perception of the Being, the desired cassation of desire and suffering, true peace, and supreme happiness (blessedness).

In essence, after the fall, God's holiness required punishment and payment (atonement) for sin, which was (and still is) eternal death. In support of this assertion, the Christian Sacred Scripture holds that "...the wages of sin is death..." However, man's death was not (and still is not) adequate to cover the payment for sin; only a perfect, spotless sacrifice could have paid for man's sin. Jesus Christ, the perfect God-man, is the God-man Redeemer who came to offer the pure, complete, and everlasting sacrifice to remove, atone, and make eternal payment for sin that had resulted to lust, universal corruption, and suffering. ${ }^{39}$ Only the God-man Redeemer, who was sinless, could redeem what Adam had lost because He was grafted into the same human nature that had become polluted by sin. In this context, the God-man Redeemer was non possere peccare (not able to sin) and would not have shared the following confession with David: "Surely, I was sinful at birth, sinful from the time my mother conceived me."

Again, the God-man Redeemer had both the ability (as God) and obligation (as man, the offender) to make the required satisfaction through the Paschal Mystery. Christ is the sole fount of redemption. By His Passion, Death, and Resurrection, Christ accomplished His salvific mission regarding the redemption of man. All in all, Christians hold that Christ is the Redeemer par excellence, man's absolute Saviour, and Man for others, who became man so that man who is created in the image of God is recreated by the person who is the Image of God. ${ }^{41}$ Also, after the fall, human nature was permeated 
with the evil energy that is technically called concupiscence. As mentioned earlier, concupiscence means humanity's natural inclination towards sin. In the second Noble Truth of Buddhism, concupiscence is the lust, that is, the evil energy in the human nature, which is the cause of human suffering. Again, concupiscence throws a light on how Christ's Death is linked to His humanity. In that vein, when Christ assumed man's nature, He also assumed the obligation, attached to that nature, to perfectly pay the demands of God's holiness in order to satisfy the offended God for man's salvation. Surely, $\mathrm{He}$ is duty-bound to carry out, through His obedience in the Paschal Mystery, this duty to full payment. For that reason, fallen in Adam, humanity that experienced lust, universal corruption, and the resultant suffering was not abandoned by God.

Along these lines, the truth of Christ's identification with humanity in natural birth, or by partaking of its nature, is the truth of His federal headship. Hence, as in Adam all die, so in Christ are all made alive, but only many made righteousNote that Christ stands to man in the same relationship that Adam did; Adam is the source of sin that led to desire, universal corruption, and suffering, but Christ is the source of grace and liberation from the said sin, desire, universal corruption, and suffering. Thus, Christ is the Second Adam, the New Adam, or the last Adam. ${ }^{44}$ All in all, as all could fall in the first Adam's disobedience, so all could be substituted in the New Adam's obedience. So, by His obedience, Christ brought about the redemptive reconciliation of man with God. Herein, Christ took man's nature by both natural generation and the Holy Spirit's conception so as to shoulder the entire human guilt devoid of original sin. Precisely, in and through Christ, God entered into the human story and history so as to redeem man from sin, desire, universal corruption, and suffering by His Son's obedience in the Paschal Mystery.

\section{Conclusion}

In essence, the heart of this article is about explaining the four Noble Truths of Buddhism in the light of Christian Soteriology. In that vein, after a simplified explanation of the four Noble Truths of Buddhism, this article endeavours to re-explain and re-express the same four Noble Truths in the light of Christian Soteriology. In short, the four Noble Truths of Buddhism are the essence of Buddha's teachings; these truths are the truth of suffering, the truth of the cause of suffering, the truth of the end of suffering, and the truth of the path that leads to the end of suffering.

In this context, on the one hand, Buddhism and Christianity agree that life is permeated with suffering. Again, these two religions teach that the cause of universal corruption and suffering is desire. But, what is the cause of desire? Christianity teaches that the cause of the said desire is the lust that resulted from man's Adamic fall. Herein, it is held that the Adamic fall of man resulted to his inherent passionate lust (desire), which brought about the woeful universal corruption and suffering. It is this desperate state of humanity that leaves it in a desperate need for salvation.

Along these lines, Buddhism holds that the path that leads to salvation (nirvana) is the Eightfold Path, whilst Christianity teaches that the much-needed redemption of humanity can be attained through the Paschal Mystery, namely, Christ's Passion, Death, and Resurrection. In a nutshell, in the light of Christian Soteriology, this article unfolds that the Four Noble Truths of Buddhism can be re-explained and re-expressed towards illuminating the Christian teaching, which holds that life is permeated with universal corruption and suffering, the cause of the said universal corruption and suffering is desire (unquenchable lust) that resulted from the fall of man, and the said universal corruption and suffering can be ceased through the Paschal Mystery that brings about salvation. In the same vein, this article evidences that various aspects of Christian Soteriology can be used to enrich a Buddhic understanding of the Four Noble Truths.

Overall, because of humanity's inherent universal desire to return to its Origin, religion is born as humanity's religious vehicle through which human beings seek to regain the Paradise that they lost after the fall. Hence, Christians and Buddhists use their respective religions and teachings as vessels that can enable them to regain their original relationship with their Origin. To that end, both religions have much to learn from each other in their respective voyages to redemption. In this context, therefore, salvation should not be seen as an exclusive Christian concept because it is an indispensable element in almost all religions. Surely, in its unique way, every religion displays a ray of truth about salvation. Generally, as revealed by Christian and Buddhic soteriologies, religions can be considered as diverse pious ways of salvation. ${ }^{7}$ Moreover, as demonstrated by Christianity and Buddhism, almost all religions teach that there is a continuation after this earthly life; nonetheless, as shown by these two religions, the nature of the said continuation and the means to it differ in different religions. All in all, via an authentic give and take relationship, Christianity and Buddhism can borrow from each other towards enriching their respective soteriologies.

\footnotetext{
${ }^{7}$ Nostra Eatate, No. 2
} 